\title{
Through British and American Eyes: Anthony Cross' Bibliography of English and American Accounts of the Russian Empire
}

\author{
Rodolphe Baudin \\ The University of Strasbourg \\ rodolphebaudin@unistra.fr
}

Anthony Cross, In the Lands of the Romanovs. An Annotated Bibliography of First-hand Englishlanguage Accounts of the Russian Empire (1613-1917). Cambridge, UK: Open Book Publishers, 2014,419 p. ISBN 978-1-78374-057-4

The fruit of a lifelong effort, A. G. Cross' latest book crowns a long list of publications devoted to the history of Anglo-Russian relations. ${ }^{1}$ Focusing on the period from the seventeenth century, which saw the publication of the first Anglophone travel accounts, to the fall of the Romanov dynasty in 1917, this annotated bibliography introduces no less than 1243 texts on Russia and the Russian empire, mostly in English, less often translated from other languages. Organizing his material chronologically, the author has divided his book into eleven chapters (named using letters from A to K) dedicated to various reigns (from Tsar Mikhail Fedorovich to Emperor Nicholas II) or prominent historical events (like the Crimean War). The final chapter, devoted to the reign of the last Romanov, also focuses on two major military conflicts (the RussoJapanese war of 1904-1906 and World War I) as well as English-language accounts of the first Russian Revolution.

This chronological approach undoubtedly makes Cross' bibliography very easy to use for scholars working on intercultural relations. No less useful are the author's annotations, which provide a useful summary of who the traveller was and what he or she was doing in Russia. Cross' annotations depict "the richness and variety of Englishlanguage [...] accounts of the Russian Empire" (61). They also highlight the diversity of "themes, trends and events" (ibid.) described in the accounts. This diversity is at the centre of the excellent introduction to the volume, which not only explains the various political and/or economic reasons that made these accounts popular at various times in British and American history, but also recounts the critical and public reception of the most famous of these texts. Following the chronology of the bibliography itself, the introduction-which can be seen as a short history of Russia-related travels and travel writing-offers a full typology of travels, travel practices, and travellers. Travels to Russia include "the Northern Tour" (a variant of the Grand Tour), scientific expeditions,

\footnotetext{
${ }^{1}$ Russia Under Western Eyes, 1517-1825, ed. with an introd. by Anthony Cross (London, Elek Books [1971]); Anglo-Russian Relations in the Eighteenth Century, exhibition devised and catalogue compiled by Anthony Cross ([Norwich]: [The author], [1977]); Peter the Great Through British Eyes: Perceptions and Representations of the Tsar Since 1698 (Cambridge: Cambridge University Press, 20oo); St Petersburg and the British: the City Through the Eyes of British Visitors and Residents (London: Frances Lincoln, 2008); and, most-famously, the author's diptych: "By the Banks of the Thames": Russians in Eighteenth Century Britain (Newtonville, Mass.: Oriental Research Partners, 1980) and By the Banks of the Neva: Chapters From the Lives and Careers of the British in Eighteenth-Century Russia (Cambridge; New York: Cambridge University Press, 1997).
} 
military campaigns, and hunting or fishing expeditions. Travel practices range from city-watching (including the odd tourism to burnt-out Moscow after 1812) and war tourism during the Crimean War, to alpinism in the Caucasus and "tramp travels." Traveller types are striking in their diversity. They include physicians (first to the tsars, then to noble families), architects, ship-builders, engineers, landscape gardeners, tutors to young aristocrats, scientists, missionaries, diplomats, military personnel, war correspondents, and even cyclists. Especially valuable is Cross' attention to the social diversity and gender of travellers to Russia. Accounts of the Crimean War, for example, were written by officers and simple soldiers alike; while female travellers, who initially went to Russia mainly as governesses and nurses, came to include more well-heeled female tourists, from both Britain and the US, in the late nineteenth century. Finally, special mention needs to be made of Anglophone "armchair travellers," who never actually went to Russia, but wrote on it following a trend or a specific political agenda. ${ }^{2}$

A major addition to the scholarship on Anglo-Russian and American-Russian historical and cultural contacts, In the Lands of the Romanovs is available in two different formats: as a paperback book and as a free publication on the publisher's website. $^{3}$ This innovative publishing practice will make it even more easily available to the Russian audience and to the student audience alike. Let us hope similar efforts are made to publish bibliographies of travel accounts to the Russian Empire in other European languages.

\footnotetext{
${ }^{2}$ Armchair travels have drawn the increasing attention of scholars in the last few years. On this topic, see Bernd Stiegler, Reisender Stillstand: eine kleine Kulturgeschichte der Reisen im und um das Zimmer herum (Frankfurt: S. Fischer, 2010); translated from the German by Peter Filkins as Traveling in Place: a History of Armchair Travel (Chicago: The University of Chicago Press, 2013).

${ }^{3} \mathrm{~A}$ free, socially enhanced version of this book is also available on Wikiversity, a Wikimedia Foundation project devoted to educational resources. This version of Cross' bibliography can be accessed via this link.
} 